\title{
Kimberlites: Descriptive Geological Nomenclature and Classification
}

\author{
B.H. Scott Smith ${ }^{1,3}$, T.E. Nowicki ${ }^{2}$, J.K. Russell ${ }^{3}$, K.J. Webb ${ }^{2}$, \\ C.M. Hetman ${ }^{2}$, M. Harder ${ }^{2}$ and R.H. Mitchell ${ }^{4}$ \\ ${ }^{I}$ Scott-Smith Petrology Inc., North Vancouver, Canada, ${ }^{2}$ Mineral Services Canada Inc., North Vancouver, Canada, \\ ${ }^{3}$ University of British Columbia, Vancouver, Canada, ${ }^{4}$ Lakehead University, Thunder Bay, Canada
}

\section{Introduction}

In this contribution, we outline a scheme for kimberlite nomenclature and classification. In contrast to the approach of Cas et al. (2008), which focuses on volcanic terminology and how it can and should be applied to kimberlite, the scheme proposed here is founded on several decades of applied kimberlite geology focused primarily on the development of practical and economically relevant geological models for primary diamond deposits. The emphasis of this contribution is on integrating the learnings and requirements of such work, as far as possible, with acceptable modern volcanological nomenclature to derive a scheme that is: i) practical to apply at all stages of an investigation of kimberlite; ii) applicable by geologists of varying experience levels; and iii) economically relevant.

\section{Key Principles and Objectives}

The aim of the scheme proposed here is to provide a practical, systematic, framework to assist in the description, recognition and understanding of the complex and unusual rocks encountered during diamond exploration. The recommended approach is illustrated in Table 1. It involves an initial descriptive stage that requires only limited genetic interpretation, followed where possible by classification of the rock into specific types based on increasing degrees of genetic interpretation. This concept is partly inspired by the approach of McPhie et al. (1993) and is similar to that outlined by Cas et al. (2008). However, there are key differences that make our approach to kimberlite nomenclature more practical. Volcanological nomenclature schemes published by McPhie et al. (1993) and Cas et al. (2008) involve an initial subdivision into one of two textural sub-types, namely coherent and volcaniclastic (or "fragmental" in the case of Cas et al., 2008). The descriptive terminology used for each type is different, thus a rock needs to be assigned to one of these textural classes before it can be described further using either of these classification schemes. Our view is that classification of rocks as either coherent or volcaniclastic involves an interpretation that commonly requires detailed observations and in certain instances it may not be possible to make this distinction. In addition, an incorrect assessment of this type of textural subdivision can be very misleading, especially with respect to predictions of deposit structure and diamond distribution. We therefore recommend an approach built on a series of descriptors that can be applied independently of textural-genetic classification. Whilst the textural-genetic classification of kimberlite is an important component of our scheme, it is considered a higher-level interpretation that is made, where possible, at a later stage in the rock naming process. Importantly, our descriptive nomenclature provides the critical information required to build economically relevant geological models for kimberlite bodies, without the need for higher-level interpretation. Key aspects of each stage of the proposed nomenclature scheme are outlined below. It is intended that a more detailed description of the scheme will be published in the 9IKC proceedings volume together with an extensive glossary of relevant terms.

\section{Stage 1: Background Information}

Stage 1 involves establishment of the setting and background to the rocks in question, capturing relevant sample details and describing contacts between lithological units.

\section{Stage 2: Rock / Unit Description}

The descriptive stage is considered to be the most critical component of the nomenclature scheme. It provides a systematic framework for the non-genetic description of rocks, either single samples or lithological units. This stage provides the evidence for the interpretations undertaken in Stages 3 to 5. Our descriptive framework follows a progressive decrease in the scale of observation from megascopic through macroscopic to microscopic. Stage 2 comprises four main parts: alteration; structure; components; and texture. The resulting description is the basis of a descriptive rock name which highlights the significant and characteristic features that can be recognised in the sample/unit. An important aspect of the scheme is the emphasis placed on the nature, abundance and size of economically significant components (i.e. olivine, other mantle-derived xenocrysts and all types of xenoliths) which can be used to predict diamond distributions even if the texture and genesis of the host rock is not understood. 
Table 1: Summary of the proposed kimberlite nomenclature and classification scheme

\begin{tabular}{|c|c|c|c|c|c|}
\hline Stage 1 & Stage 2 & Stage 3 & Stage $4 a$ & Stage $4 b$ & Stage 5 \\
\hline \multicolumn{2}{|c|}{ OBSERVATION } & \multicolumn{4}{|c|}{ PROGRESSIVE INTERPRETATION } \\
\hline $\begin{array}{l}\text { Background } \\
\text { Information }\end{array}$ & Rock Description & $\begin{array}{l}\text { Petrogenetic } \\
\text { Classification }\end{array}$ & Tex & ural-Genetic Classification & $\begin{array}{l}\text { Genetic/ Process } \\
\text { Interpretation }\end{array}$ \\
\hline $\begin{array}{l}\text { Setting: } \\
\text { geographic; tectonic; } \\
\text { geological; structural; } \\
\text { igneous association; } \\
\text { age relationships; } \\
\text { emplacement styles } \\
\text { Sample details: } \\
\text { type; attributes; } \\
\text { location } \\
\text { Scope of study: } \\
\text { context and aim of } \\
\text { investigation } \\
\text { Contacts: } \\
\text { preservation; dip; } \\
\text { nature; relationship } \\
\text { and timing of units }\end{array}$ & $\begin{array}{l}\text { Alteration: } \\
\text { intensity; distribution; mineralogy; } \\
\text { timing; imposed textures; } \\
\text { preservation; xenolith reaction } \\
\text { Structure: } \\
\text { e.g. massive; inhomogeneous; } \\
\text { banded }\end{array}$ & $\begin{array}{l}\text { Parental magma type: } \\
\text { e.g. kimberlite; lamproite; } \\
\text { melnoite; alnoite; olivine } \\
\text { melilitite }\end{array}$ & $\begin{array}{l}\begin{array}{l}\text { Coherent: } \\
\text { [descriptors] } \\
\text { coherent } \\
\text { kimberlite (CK) }\end{array} \\
\\
\\
\text { Volcaniclastic: } \\
\text { [descriptors] } \\
\text { volcaniclastic } \\
\text { kimberlite (VK) }\end{array}$ & 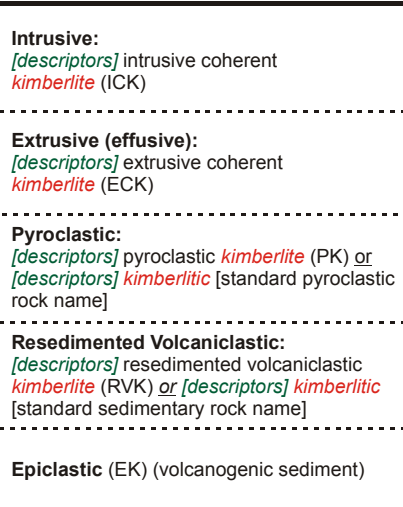 & 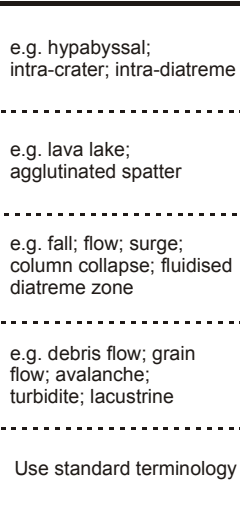 \\
\hline $\begin{array}{l}\text { Example names: } \\
\text { glacial boulder; } \\
\text { outcrop sample; } \\
\text { drillcore intersection } \\
\text { bounded by sharp } \\
\text { parallel contacts }\end{array}$ & $\begin{array}{l}\text { Example names: fresh, uniform, } \\
\text { xenolith-poor, medium-grained, } \\
\text { olivine macrocryst-rich rock; } \\
\text { intensely serpentinised, massive, } \\
\text { xenolith-rich, fine to medium } \\
\text { grained, olivine-poor rock }\end{array}$ & $\begin{array}{l}\text { Example names: moderately } \\
\text { macrocryst-rich carbonate } \\
\text { phlogopite monticellite } \\
\text { kimberlite; phlogopite olivine } \\
\text { lamproite; macrocryst-poor } \\
\text { phlogopite orangeite }\end{array}$ & $\begin{array}{l}\text { Example names: } \\
\text { xenolith-poor, flow } \\
\text { zoned, variably } \\
\text { macrocrystic CK; } \\
\text { xenolith-rich, well } \\
\text { bedded VK }\end{array}$ & $\begin{array}{l}\text { Example names: uniform ICK; bedded PK; } \\
\text { olivine-rich kimberlitic lapilli tuff; xenolith- } \\
\text { dominant Wesselton-type VK; } \\
\text { inhomogeneous RVK; well-sorted } \\
\text { olivine-rich kimberlitic sandstone; } \\
\text { kimberlitic mudstone }\end{array}$ & \\
\hline
\end{tabular}

The recommended Stage 2 descriptors overlap substantially with those of Cas et al. (2008) but we include some key modifications:

- $\quad$ use a single set of non-genetic size descriptors for crystals (primarily olivine) that can be applied to both coherent and volcaniclastic rocks (Table 2);

- discontinue usage of the term breccia to indicate a certain proportion of xenolithic material and replace with specific xenolith abundance descriptors $(>0,<15 \%=$ xenolith-bearing; $15-50 \%$ $=$ xenolith-rich; $50-75 \%=$ very xenolith-rich; $>75 \%=$ xenolith-dominated);

- retain the term magmaclast as a non-genetic descriptive term for solidified juvenile meltbearing clasts formed during or prior to emplacement by any process of disruption (includes pyroclasts and magmatic segregations) and does not include melt-free discrete crystals.

Table 2: Non-genetic size descriptors for all crystals

\begin{tabular}{llc}
\hline $\begin{array}{l}\text { Size range } \\
(\mathrm{mm})\end{array}$ & Descriptor & Abbreviation \\
\hline$<0.125$ & ultrafine & uf \\
$0.125-0.25$ & superfine & $\mathrm{sf}$ \\
$0.25-0.5$ & very very fine & $\mathrm{vvf}$ \\
$0.5-1$ & very fine & $\mathrm{vf}$ \\
$1-2$ & fine & $\mathrm{f}$ \\
$2-4$ & medium & $\mathrm{m}$ \\
$4-8$ & coarse & $\mathrm{C}$ \\
$8-16$ & very coarse & vc \\
$>16$ & ultracoarse & uc \\
\hline
\end{tabular}

\section{Stage 3: Petrogenetic Classification}

Stage 3 involves identification of the magmatic mineral assemblage and, on that basis, classification of the rock or parental magma type (e.g. kimberlite, lamproite, alnoite etc.) and further mineralogical descriptors. This stage requires the identification of the products of crystallisation and is best done on either fresh holocrystalline coherent rocks or magmaclasts. The magma type and mineralogical classification is of prime economic significance, i) to confirm that the rock is kimberlite or similar related rock with the potential to contain diamonds and, ii) to identify different phases of kimberlite intrusion or eruption within a particular body.

\section{Stage 4: Textural-Genetic Classification}

Two stages of textural-genetic classification (Table 1) require increasing information and interpretation. The term coherent is applied to rocks formed by the solidification of magma lacking evidence for magmatic fragmentation or disruption (pyroclastic features). Volcaniclastic is the preferred non-genetic term applied to deposits and rocks composed of a substantial proportion of volcanic particles. This includes clastic rocks occurring within the diatreme or conduit zone of volcanic pipes. Where the magma type is known, this is applied as the rock name (e.g. coherent kimberlite or volcaniclastic kimberlite).

Where further textural genetic classification is possible, volcaniclastic rocks can be more specifically assigned to three higher order designations, i.e. pyroclastic, resedimented volcaniclastic and epiclastic (volcanogenic sedimentary). In principle, the name 
kimberlite (or any other parent magma type) is not an appropriate term for an aggregate of clastic material particularly for rocks which contain material from other sources. In particular, the characteristics of resedimented volcaniclastic and epiclastic rocks can differ substantially from the coherent material on which most magma-type classifications are based. So, while these rocks may be described as kimberlitic (to signify their origin from a kimberlite volcano), they are not kimberlite sensu-stricto and an alternative rock name may be more suitable. Where appropriate, standard volcanological and sedimentological rock names can be applied at this stage. These should be prefixed by the magma type (e.g. kimberlitic) where this is known (see examples in Table 1).

\section{Stage 5: Genetic / Process Interpretation}

Stage 5 involves integrating the information obtained in Stages 1 to 4 to interpret the process by which a rock formed. Cas et al. (2008; Tables 11 and 12) provide a useful list of emplacement origins and settings for coherent and volcaniclastic rocks. These are based on well-known processes and products in other volcanic systems and many of them also occur in kimberlite volcanoes. Due to the unusual characteristics of kimberlite magmas, in particular their high proportion of solids (mostly in the form olivine xenocrysts) and volatiles $\left(\mathrm{CO}_{2}\right.$ and $\left.\mathrm{H}_{2} \mathrm{O}\right)$, certain unique kimberlitespecific deposit types can also occur. Furthermore, the focus of most kimberlite studies on material occurring within the pipe is unusual in the volcanology context and can be expected to reveal processes and products that are not well known or understood in other volcanic settings.

\section{The Rock Formerly Known as TK}

Tuffisitic kimberlite (TK) is a distinctive textural variety of kimberlite (e.g. Table 1 of Hetman, 2008; Mitchell et al., 2008) which has been emplaced worldwide and over an extensive time period (at least 1200 to $90 \mathrm{Ma}$.). It has long been recognised that the term TK is not appropriate but finding a replacement term is problematic, especially given current diverse views on their nature and origin. While this rock type commonly can be described as massive volcaniclastic kimberlite (e.g. Sparks et al., 2006), this term is very general and also includes a wide range of other volcaniclastic rock types with features indicating a range of different origins (Table 1 of Hetman, 2008). Thus we suggest the general term Wesselton-type volcaniclastic kimberlite (with appropriate descriptors as prefixes) to denote the specific rock type that was previously known as TK. The Wesselton Mine is one of the pipes in Kimberley, South Africa. This is not only a type area for fresh archetypal holocrystalline kimberlite but also contains significant quantities of TK. Both of these rock types have been examined in detail (e.g. Mitchell et al., 2008 and references therein). Massive is a descriptor which can be added when appropriate; it describes many, but not, all tuffisitic kimberlites. The subdivision of kimberlite pipes into crater, diatreme and root zones is well entrenched in kimberlite literature. We support retaining these terms but emphasise that they should only be used in a strictly descriptive sense to designate the morphology and relative vertical location of the portion of the deposit being described. Pipe zone terms should not be used to denote a specific process of formation or type of infill material.

\section{Application}

The nomenclature approach outlined in this paper provides a sound basis for the development of geological models required for kimberlite exploration, evaluation, resource classification and mining. Critically, it focuses on key descriptive criteria that permit reliable and relevant application at an early stage of investigation and by geologists that are not necessarily kimberlite experts. Nonetheless, the level to which the scheme can be applied, and thus the degree of confidence in the outcome, depends on the nature of the rocks, the experience of the user with these rock types and the level of detail of the investigation. Understanding the different and varying degrees of confidence in the conclusions is important, particularly in the economic application of the results. The degree of confidence reflects (i) the accuracy of the recognition of primary features and constituents in Stages 1 and 2, and (ii) the validity of the interpretation of that evidence in Stages 3 to 5 .

\section{References}

Cas, R.A.F., Porritt, L., Pittari, A., Hayman, P., 2008. A new approach to kimberlite facies terminology using a revised general approach to the nomenclature of all volcanic rocks and deposits: Descriptive to genetic. Journal of Volcanology and Geothermal Research, 174. In press.

Hetman, C.M., 2008. Tuffisitic kimberlite (TK): a Canadian perspective on a distinctive textural variety of kimberlite. Journal of Volcanology and Geothermal Research, 174, 57-67.

McPhie, J., Doyle, M., Allen, R., 1993. Volcanic Textures. Centre of Ore Deposit and Exploration Studies, University of Tasmania. $196 \mathrm{pp}$.

Mitchell, R.H., Skinner, E.M.W., Scott Smith, B.H., 2008. Tuffisitic kimberlites: mineralogical characteristics relevant to their formation. This volume.

Sparks, R.S.J., Baker, L., Brown, R.J., Field, M., Schumacher, J., Stripp, G., Walters, A., 2006. Dynamical constraints of kimberlite volcanism. Journal of Volcanology and Geothermal Research $155,18-48$. 